\title{
Pengaruh Komposisi Air Limbah Industri Kertas sebagai Media Pertumbuhan dan Fotoperiode terhadap Kultur Spirulina platensis
}

\author{
Meisa Legi Rizkiana ${ }^{1 *+}$, Saepulloh ${ }^{2+}$, Prima Besty Asthary ${ }^{2}$, Rahmaniar Mulyani ${ }^{1}$ \\ ${ }^{1}$ Universitas Jenderal Achmadyani, Jalan Terusan Jendral Sudirman, Cimahi \\ ${ }^{2}$ Balai Besar Pulp dan Kertas, Jalan Raya Dayeuhkolot No. 132 Bandung
}

Diterima : 06 Mei 2019, Revisi akhir : 22 Juni 2019, Disetujui terbit : 26 Juni 2019

\section{The Effect of Composition of Paper Industry Wastewater as A Growth Medium and Photoperiod on The Culture of Spirulina platensis}

\begin{abstract}
The paper industry produces wastewater from its production activities and the flue gas desulphurization process (wet scrubber wastewater). Nutritional compounds (carbon, nitrogen and phosphate compounds) which are still in treated wastewater and wet scrubber wastewater have not been utilized optimally and have potential as growth medium of Spirulina platensis. Research on wastewater compositions and photoperiod variations (24 hours light and 12 hours light/12 hours dark) was carried out on a laboratory scale for 9 days. Measurements of medium $\mathrm{pH}$, growth of S. platensis (biomass concentration, specific growth rate, and doubling time), and phycocyanin content were carried out every day to study the effect of wastewater composition and photoperiod treatment on the growth of S. platensis. The results showed that $S$. platensis can grow well on all compositions of treated wastewater and wet scrubber wastewater. The highest biomass concentration of $831 \mathrm{mg} / \mathrm{L}$ and the highest specific growth rate of 0.52 days $\mathrm{s}^{-1}$ with a doubling time of 0,4 days is obtained from 24-hour light photoperiod treatment. The composition of treated wastewater and wet scrubber wastewater has no significant effect on the biomass concentration but the photoperiod differences greatly influence the biomass concentration so that in the field scale application it is necessary to consider the lighting system for optimal S. platensis growth.
\end{abstract}

Keywords: Spirulina platensis, growth medium, photoperiod, treated wastewater, wet scrubber wastewater

\begin{abstract}
Abstrak
Industri kertas menghasilkan air limbah dari kegiatan produksi dan proses flue gas desulphurization (air limbah wet scrubber). Senyawa nutrisi (senyawa karbon, nitrogen, dan fosfat) yang masih terdapat dalam air limbah terolah dan air limbah wet scrubber belum dimanfaatkan secara optimal dan berpotensi sebagai media pertumbuhan Spirulina platensis. Penelitian dengan variasi komposisi air limbah dan fotoperiode ( 24 jam terang dan 12 jam terang/ 12 jam gelap) telah dilakukan dalam skala laboratorium selama 9 hari. Pengukuran $\mathrm{pH}$ media, pertumbuhan S. platensis (konsentrasi biomassa, laju pertumbuhan spesifik, dan waktu penggandaan), dan kandungan fikosianin dilakukan setiap hari untuk melihat pengaruh komposisi media dan perlakuan fotoperiode terhadap pertumbuhan S. platensis. Hasil menunjukkan bahwa S. platensis dapat tumbuh dengan baik pada semua komposisi air limbah terolah dan air limbah wet scrubber yang diujicobakan. Konsentrasi biomassa tertinggi sebesar $831 \mathrm{mg} / \mathrm{L}$ dan laju pertumbuhan spesifik tertinggi sebesar 0,52 hari $^{-1}$ dengan waktu penggandaan 0,4 hari diperoleh dari perlakuan fotoperiode 24 jam terang. Komposisi air limbah terolah dan air limbah wet scrubber tidak memberikan pengaruh yang nyata terhadap konsentrasi biomassa, tetapi perbedaan fotoperiode sangat berpengaruh terhadap konsentrasi biomassa sehingga dalam aplikasi skala lapangan perlu mempertimbangkan sistem pencahayaan untuk pertumbuhan S. platensis yang optimal.
\end{abstract}

Kata kunci: Spirulina platensis, media pertumbuhan, fotoperiode, air limbah terolah, air limbah wet scrubber 


\section{Pendahuluan}

Industri kertas merupakan salah satu industri yang mengonsumsi air bersih dalam jumlah yang banyak untuk kegiatan produksinya sekaligus sebagai penghasil air limbah yang banyak pula (Ashrafi, Yerushalmi and Haghighat, 2015). Air limbah yang dihasilkan oleh industri kertas dapat mencapai $60 \mathrm{~L}$ air limbah untuk setiap kg kertas yang diproduksinya (Thompson et al., 2001; Doble and Kumar, 2005). Air limbah industri kertas mengandung beragam senyawa organik dan anorganik yang harus dihilangkan melalu beberapa tahapan pengolahan pada Intalasi Pengolahan Air Limbah (IPAL) sebelum dibuang ke lingkungan. Energi yang diperlukan untuk pengolahan air limbah cukup besar berkisar 0,5-2 $\mathrm{kWh} / \mathrm{m}^{3}$ tergantung jumlah dan komposisi air limbah serta proses pengolahan air limbah yang berlangsung (Gude, 2015), namun secara umum, air limbah mempunyai energi potensial yang cukup besar dimana sampai $26 \%$ berupa energi kimia dalam bentuk senyawa organik dan unsur-unsur senyawa nutrisi seperti senyawa nitrogen dan fosfor (Kokabian and Gude, 2015; Gude, 2016). Pembuangan air limbah yang masih banyak mengandung senyawa nutrisi ke badan air dapat mengakibatkan terjadinya pertumbuhan fitoplankton yang tidak terkendali (phytoplankton bloom) (Cai, Park and Li, 2013). Asthary et al. (2013) menjelaskan bahwa meskipun air limbah sudah mengalami proses pengolahan, air limbah terolah (efluen) industri kertas masih mengandung senyawa organik dan unsur hara nitrogen dan fosfor yang berpotensi menyebabkan eutrofikasi apabila langsung dibuang ke badan air. Gude, Kokabian and Gadhamshetty (2013) menjelaskan bahwa dengan memanfaatkan energi dari bahan kimia (senyawa organik dan nutrisi) yang terkandung dalam air limbah, pengolahan air limbah dapat berubah dari proses yang memerlukan energi menjadi proses yang menghasilkan energi selain untuk menghilangkan polutan yang membahayakan lingkungan.

Mikroalga merupakan mikroorganisme fotosintetik yang dapat tumbuh dengan memanfaatkan cahaya, sumber karbon, $\mathrm{CO}_{2}, \mathrm{~N}$, $\mathrm{P}$, dan $\mathrm{K}$ kemudian mengonversinya menjadi lipid, karbohidrat, dan protein dalam jumlah yang banyak dengan waktu yang relatif singkat (Demirbas, 2011). Dalam pengolahan air limbah, Cai, Park and Li (2013) menjelaskan bahwa mikroalga dapat mengurangi senyawa nitrogen, fosfor, dan logam-logam beracun yang terkandung dalam air limbah secara efektif. Selain mengurangi konsentrasi nutrisi (senyawa $\mathrm{N}$ dan $\mathrm{P}$ ) dalam air limbah, pemanfaatan mikroalga dalam pengolahan air limbah juga dapat menghasilkan biomassa yang dapat digunakan sebagai bahan baku pembuatan biofuel sehingga budidaya mikroalga yang digabungkan dalam pengolahan air limbah merupakan salah satu alternatif dalam mengatasi masalah eutrofikasi sekaligus masalah keterbatasan energi (Chang et al., 2013). Lebih lanjut Chang et al. (2013) menjelaskan bahwa budidaya mikroalga pada umumnya menggunakan pupuk sebagai sumber utama nutrisi bagi pertumbuhan mikroalga yang mengakibatkan biaya budidaya mikroalga tinggi, bisa mencapai $25 \%$ dari total biaya (Rodrigues et al., 2010). Apabila media pertumbuhan mikroalga dapat diganti dengan air limbah seperti air limbah domestik, pertanian, atau limbah industri, budidaya mikroalga dapat lebih berkelanjutan secara ekonomi.

Mikroalga Spirulina platensis merupakan salah satu alga hijau-biru yang telah banyak diteliti karena kandungan nutrisinya, baik pada bidang industri makanan, kesehatan, maupun akuakultur (Bertolin et al., 2011; Colla et al., 2015). Mikroalga S. platensis tidak hanya memiliki kandungan protein yang tinggi tetapi juga mengandung asam amino, lipid, asam lemak, karbohidrat, vitamin, mineral, dan pigmen (Blinkova, Gorobets and Baturo, 2001; Ono and Cuello, 2004; Bezerra et al., 2012) sehingga dapat dijadikan sebagai suplemen makanan yang komplit (Soni, Sudhakar and Rana, 2017). Kandungan fikosianin dalam S. platensis tidak hanya dapat berfungsi sebagai pewarna alami, tetapi juga dapat berfungsi sebagai antiinflamasi dan antioksidan (Romay et al., 1998; Bermejo, Piñero and Villar, 2008; Kuddus et al., 2013).

Beberapa penelitian juga menunjukkan bahwa S. platensis berpotensi menjadi bahan baku dalam pembuatan bahan bakar alternatifyang terbarukan. S. platensis berpotensi untuk dijadikan bahan baku pembuatan biodiesel meskipun kandungan lipid pada $S$. platensis tidak setinggi pada mikroalga lainnya karena laju pertumbuhan sel S. platensis yang tinggi (Rodrigues et al., 2010; Kim et al., 2013; Sumprasit et al., 2017). Bahkan lebih lanjut Rajak and Verma (2018) menjelaskan bahwa biodiesel yang dibuat dengan bahan baku S. platensis dapat menjadi alternatif pengganti bahan bakar diesel untuk beberapa jenis mesin 
diesel. Kandungan karbohidrat yang cukup tinggi pada $S$. platensis juga berpotensi menjadi bahan baku pembuatan bioetanol melalui proses sakarifikasi dan fermentasi (Braga et al., 2018, 2019). Selain itu, protein yang terkandung dalam $S$. platensis juga dapat dikonversi menjadi biocrude oil melalui hydrothermal liquefaction (Chang et al., 2013).

Hasil penelitian yang telah dilakukan oleh Asthary et al. (2013) dan Setiawan et al. (2014) menunjukkan bahwa air limbah terolah dari industri kertas dapat dijadikan media alternatif pertumbuhan $S$. platensis bahkan sampai komposisi $100 \%$. Kemampuan S. platensis untuk dapat tumbuh dalam media air limbah terolah disebabkan oleh kelebihan yang dimiliki oleh $S$. platensis, yaitu dapat tumbuh pada kondisi media yang bersifat alkali seperti air laut dan air limbah (Kim et al., 2013) dan relatif tahan terhadap kontaminasi dari mikroorganisme lain yang dapat menggangu pertumbuhan S. platensis (Eriksen, 2008) serta fleksibel dan resisten terhadap kondisi pertumbuhan suboptimal (Rodrigues et al., 2010). Selain itu, $S$. platensis dapat tumbuh baik secara fotoautotrof, heterotrof, maupun miksotrofik (mixotrophic) dimana pada kondisi tersebut $S$. platensis dapat memperoleh energi dari proses fotosintesis (fotoautotrof) sekaligus dari sumber karbon organik (heterotrof) (Lee, 2004; Cheirsilp and Torpee, 2012). Pada penelitian yang telah dilakukan oleh Setiawan et al., (2014) air limbah terolah digunakan sebagai sumber nutrisi dan mineral sedangkan $\mathrm{CO}_{2}$ dari emisi pembakaran batubara digunakan sebagai sumber karbon.

Industri kertas, khususnya yang menggunakan batu bara sebagai bahan bakar pada unit boiler, juga menghasilkan air limbah dari proses Flue Gas Desulphurization (FGD) secara wet scrubber (air limbah wet scrubber). Air limbah wet scrubber memiliki $\mathrm{pH}$ rendah dan mengandung partikulat, sulfat, dan nitrat sehingga harus diolah terlebih dahulu sebelum dibuang ke badan air (Jo et al., 2015). Hasil penelitian yang telah dilakukan oleh Khairunnissa et al. (2018) menunjukkan bahwa air limbah wet scrubber juga dapat menjadi media alternatif untuk pertumbuhan S. platensis. Pada penelitian tersebut gas karbondioksida terlarut, senyawa nitrat, dan sulfat yang terdapat pada air limbah wet scrubber digunakan sebagai nutrisi bagi pertumbuhan S. platensis mensubtitusi sebagian nutrisi yang terdapat pada media Zarrouk.
Saat ini, belum ada penelitian yang menggunakan air limbah terolah dan air limbah wet scrubber secara bersamaan sebagai media pertumbuhan $S$. platensis. Pemanfaatkan kandungan nutrisi pada air limbah terolah dan air limbah wet scrubber sebagai media pertumbuhan $S$. platensis tidak hanya akan mengurangi beban biaya karena harga bahan kimia untuk pembuatan media yang mahal, tetapi juga dapat menjadi alternatif pemanfaatkan kedua air limbah tersebut yang selama ini belum optimal. Selain itu, hal ini juga dapat membantu mengatasi potensi terjadinya eutrofikasi apabila air limbah terolah dibuang langsung ke lingkungan (Asthary et al., 2013).

Pertumbuhan $S$. platensis tidak hanya dipengaruhi oleh kandungan bahan kimia atau nutrisi pada media tetapi juga dipengaruhi oleh faktor lingkungan. Cahaya merupakan faktor lingkungan yang sangat penting bagi pertumbuhan $S$. platensis karena diperlukan untuk proses fotosintesis (Budiardi, Utomo and Santosa, 2010). Hasil penelitian yang telah dilakukan oleh Yuan et al. (2011) dan Manullang, Widianingsih dan Endrawati (2012) menunjukkan bahwa pertumbuhan dan kandungan biokimia S. platensis dipengaruhi oleh periode waktu pencahayaan (fotoperiode).

Penelitian ini dilakukan untuk mengetahui pengaruh air limbah terolah dan air limbah wet scrubber sebagai media pertumbuhan dan fotoperiode terhadap pertumbuhan $S$. platensis termasuk pengaruhnya terhadap kandungan fikosianin yang merupakan pigmen utama dari S. platensis (Kuddus et al., 2013). Fotoperiode divariasikan antara 24 jam terang dengan pencahayaan 12 jam terang dan 12 jam gelap untuk menyimulasikan kondisi pertumbuhan $S$. platensis apabila dibudidayakan dalam skala lapangan.

\section{Bahan dan Metode}

Bahan yang digunakan dalam penelitian antara lain kultur induk S. platensis dari Pusat Penelitian Bioteknologi LIPI; air limbah terolah dan air limbah wet scrubber diperoleh dari salah satu industri kertas yang berada di Jawa Barat; buffer fosfat $\mathrm{pH} 7$; dan bahan kimia untuk pembuatan media perbanyakan S. platensis (media Zarrouk) yang terdiri dari $\mathrm{NaHCO}_{3}, \mathrm{NaNO}_{3}, \mathrm{~K}_{2} \mathrm{SO}_{4}, \mathrm{NaCl}$, $\mathrm{K}_{2} \mathrm{HPO}_{4}, \mathrm{Na}_{2} \mathrm{EDTA}, \mathrm{CaCl}_{2}, \mathrm{FeSO}_{4} .7 \mathrm{H}_{2} \mathrm{O}$, dan $\mathrm{MgSO}_{4}$ dengan kualitas analyzed grade yang diperoleh dari Merck. Peralatan yang digunakan antara lain botol kaca $500 \mathrm{~mL}$, autoklaf, aerator, 
penyaring vakum, kertas saring Whatman, lampu neon, $\mathrm{pH}$ meter YSI 100A, neraca analitik merek Ohaus, oven merek Memmert, spektrofotometer merek Hach DR2000, desikator, light meter, dan sentrifuga merek Fisher Scientific. Air limbah wet scrubber yang digunakan pada penelitian ini sama dengan penelitian yang telah dilakukan oleh (Khairunnissa et al., 2018).

\section{Karakterisasi Air Limbah Terolah dari IPAL Industri Kertas dan Air Limbah dari Proses Wet Scrubber}

Air limbah terolah dan air limbah wet scrubber yang digunakan sebagai media tumbuh $S$. platensis terlebih dahulu dikarakterisasi untuk mengetahui potensi kedua air limbah tersebut sebagai media pertumbuhan $S$. platensis. Parameter yang diuji, yaitu pH (SNI 06-6989.11-2004), total nitrogen (06-6989.52-2005), padatan tersuspensi (SNI 698.3-2004), BOD (SNI 6989.72-2009), COD (SNI 6989.73-2009), dan sulfat (SNI 6989.202009).

\section{Pengukuran Konsentrasi Biomassa S. platensis berdasarkan Nilai Kerapatan Optik (OD $\left.{ }_{680}\right)$}

Pengukuran konsentrasi biomassa S. platensis dilakukan dengan menggunakan kurva kalibrasi yang dibuat dengan mengacu pada penelitian yang dilakukan oleh Khairunnissa et al. (2018) dan Chen et al. (2013). Pada pembuatan kurva kalibrasi, pengukuran kerapatan optik (optical density) dilakukan dengan menggunakan spektrofotometer pada panjang gelombang $680 \mathrm{~nm}$ $\left(\mathrm{OD}_{680}\right)$, sedangkan konsentrasi biomassa $S$. platensis diukur secara gravimetri. Biomassa $S$. platensis dicuci dengan akuades kemudian dikeringkan dalam oven pada temperatur $105^{\circ} \mathrm{C}$ selama 1 jam hingga diperoleh berat konstan. Nilai serapan pada panjang gelombang $680 \mathrm{~nm}$ untuk setiap kultur hasil pengenceran diplot terhadap konsentrasi biomassanya sehingga terbentuk kurva kalibrasi. Kurva kalibrasi digunakan sebagai dasar dalam perhitungan konsentrasi biomassa $S$. platensis berdasarkan hasil pengukuran kerapatan optik kultur S. platensis (Dianursanti dan Wijanarko, 2007).

Kelinieran hubungan antara kerapatan optik $\left(\mathrm{OD}_{680}\right)$ dengan konsentrasi biomassa $S$. platensis dapat dilihat berdasarkan nilai regresi dari kurva kalibrasi yang diperoleh. Persamaan linier kurva kalibrasi (Persamaan 1) dengan nilai $\mathrm{R}^{2}=0,9931$ digunakan sabagai dasar perhitungan konsentrasi biomassa $S$. platensis. Konsentrasi biomassa S. platensis pada kultur yang telah diketahui nilai serapannya pada panjang gelombang $680 \mathrm{~nm}$ dihitung dengan menggunakan persamaan yang digunakan oleh Leduy and Therien (1977) dan Chang et al. (2013) dengan modifikasi (Persamaan 2).

$\mathrm{y}=217,27 x-4,3455$

Biomassa $(\mathrm{g} / \mathrm{L})=\left(217,27 \times \mathrm{OD}_{680}\right)-4,3455 \ldots$

\section{Perbanyakan Kultur S. platensis}

Kultur S. platensis diperbanyak dengan menggunakan media Zarrouk (Vieira Costa, Colla and Duarte Filho, 2004) yang mengandung $\mathrm{NaHCO}_{3} 16,8 \mathrm{~g} / \mathrm{L} ; \mathrm{NaNO}_{3} 2,5 \mathrm{~g} / \mathrm{L} ; \mathrm{K}_{2} \mathrm{SO}_{4} 1 \mathrm{~g} / \mathrm{L}$; $\mathrm{NaCl} 1 \mathrm{~g} / \mathrm{L} ; \mathrm{K}_{2} \mathrm{HPO}_{4} 0,5 \mathrm{~g} / \mathrm{L} ; \mathrm{Na}_{2}$ EDTA $0,08 \mathrm{~g} / \mathrm{L}$; $\mathrm{CaCl}_{2} 0,04 \mathrm{~g} / \mathrm{L} ; \mathrm{FeSO}_{4} .7 \mathrm{H}_{2} \mathrm{O} 0.01 \mathrm{~g} / \mathrm{L}$ dan $\mathrm{MgSO}_{4}$ $0,2 \mathrm{~g} / \mathrm{L}$. Kultur $S$. platensis diperbanyak pada temperatur ruang dengan pencahayaan selama 24 jam yang berasal dari lampu neon dan $\mathrm{pH}$ media diatur pada rentang 9-10. Perbanyakan kultur $S$. platensis dilakukan hingga masih berada pada fase log sesuai dengan kurva pertumbuhan (tidak ditampilkan dalam naskah), yaitu sekitar 4-6 hari.

\section{Percobaan Variasi Media dan Variasi Fotoperiode}

Penelitian ini menggunakan rancangan acak lengkap dengan 5 (lima) perlakuan variasi komposisi media dan 2 (dua) perlakuan fotoperiode (Tabel 1) dengan kontrol media Zarrouk. Masing-masing perlakuan dilakukan dengan 3 (tiga) kali pengulangan. Percobaan dilakukan dengan menggunakan botol kaca dengan volume $500 \mathrm{~mL}$ pada suhuruang $\left(28-30^{\circ} \mathrm{C}\right)$. Pencahayaan menggunakan lampu neon dengan intensitas sebesar \pm 4000 lux serta pengadukan dengan cara aerasi menggunakan pompa udara.

Percobaan dilakukan selama 9 hari dan setiap hari dilakukan pengukuran $\mathrm{pH}$ dan sampling kultur S. platensis untuk pengukuran kerapatan optik $\left(\mathrm{OD}_{680}\right)$ dan analisis kandungan fikosianin (Khairunnissa et al., 2018). Pengukuran pH dilakukan dengan menggunakan $\mathrm{pH}$ meter, sedangkan kerapatan optik $\left(\mathrm{OD}_{680}\right)$ diukur menggunakan spektrofotometer. Konsentrasi S. platensis dihitung berdasarkan pengukuran 
Tabel 1. Rancangan Percobaan

\begin{tabular}{lccccc}
\hline & \multicolumn{3}{c}{ Variasi Media } & \multicolumn{2}{c}{ Variasi Fotoperiode } \\
\cline { 2 - 6 } Kode & $\begin{array}{c}\text { Air Limbah } \\
\text { Terolah }\end{array}$ & $\begin{array}{c}\text { Air Limbah Wet } \\
\text { Scrubber }\end{array}$ & $\begin{array}{c}\text { Media } \\
\text { Zarrouk }\end{array}$ & $\begin{array}{c}\text { Terang } \\
(\text { Jam) }\end{array}$ & $\begin{array}{c}\text { Gelap } \\
\text { (Jam) }\end{array}$ \\
\hline A1 & $100 \%$ & $0 \%$ & $0 \%$ & 24 & - \\
B1 & $75 \%$ & $25 \%$ & $0 \%$ & 24 & - \\
C1 & $50 \%$ & $50 \%$ & $0 \%$ & 24 & - \\
D1 & $25 \%$ & $75 \%$ & $0 \%$ & 24 & - \\
E1 & $0 \%$ & $100 \%$ & $0 \%$ & 24 & - \\
K1 & $0 \%$ & $0 \%$ & $100 \%$ & 24 & - \\
A2 & $100 \%$ & $0 \%$ & $0 \%$ & 12 & 12 \\
B2 & $75 \%$ & $25 \%$ & $0 \%$ & 12 & 12 \\
C2 & $50 \%$ & $50 \%$ & $0 \%$ & 12 & 12 \\
D2 & $25 \%$ & $75 \%$ & $0 \%$ & 12 & 12 \\
E2 & $0 \%$ & $100 \%$ & $0 \%$ & 12 & 12 \\
K2 & $0 \%$ & $0 \%$ & $100 \%$ & 12 & 12 \\
\hline
\end{tabular}

$\mathrm{OD}_{680}$ menggunakan persamaan 2. Data konsentrasi $S$. platensis selanjutnya dianalisis secara statistik (ANOVA) dengan tingkat kepercayaan 95\% menggunakan program SPSS dan dijadikan dasar dalam perhitungan laju pertumbuhan spesifik dan waktu penggandaan yang dihitung dengan menggunkan persamaan 3 dan persamaan 4 (Vonshak, 1997; Budiardi, Utomo and Santosa, 2010; Chang et al., 2013). Laju pertumbuhan spesifik $(\mu)$ menunjukkan pertambahan konsentrasi biomassa $S$. platensis untuk setiap satuan waktu (hari) sedangkan waktu penggandaan atau waktu generasi (g) menunjukkan waktu yang diperlukan oleh S. platensis untuk menggandakan populasi biomassanya.

$$
\mu=\frac{\left(\ln x_{2}-\ln x_{1}\right)}{\left(\mathrm{t}_{2}-\mathrm{t}_{1}\right)}
$$

Keterangan :

$\mu \quad=$ laju pertumbuhan spesifik (hari $\left.{ }^{-1}\right)$

$\mathrm{t}_{1}$ dan $\mathrm{t}_{2}=$ waktu pertumbuhan (hari)

$\mathrm{x}_{1}$ dan $\mathrm{x}_{2} \quad=$ konsentrasi biomassa $S$. platensis pada interval waktu $\mathrm{t}_{1}$ dan $\mathrm{t}_{2}(\mathrm{mg} / \mathrm{L})$

$$
\mathrm{g}=\frac{\ln _{2}}{\mu}
$$

Keterangan :

g = waktu penggandaan (hari)

$\mu \quad=$ laju pertumbuhan spesifik $\left(\right.$ hari $\left.^{-1}\right)$
Analisis kandungan fikosianin pada kultur S. platensis dilakukan dengan mengacu penelitian yang telah dilakukan oleh Ajayan, Selvaraju dan Thirugnanamoorthy (2012). Ekstraksi fikosianin dilakukan dengan menggunakan pelarut buffer fosfat $\mathrm{pH}$ 7. Sampel dibekukan pada suhu $0^{\circ} \mathrm{C}$ selama 24 jam, kemudian dicairkan kembali (freezingthawing method). Setelah itu, dilakukan sentrifugasi untuk memisahkan supernatan dari biomassa $S$. platensis. Nilai serapan supernatan diukur dengan menggunakan spektrofotometer pada panjang gelombang $(\lambda) 615$ dan $652 \mathrm{~nm}$. Konsentrasi fikosianin (PC) dihitung dengan menggunakan persamaan 5 (Bennet and Bogorad, 1973; Ajayan, Selvaraju and Thirugnanamoorthy, 2012)

$$
\mathrm{PC}=\frac{\left(\mathrm{OD}_{615}-\left(0,474 \times \mathrm{OD}_{652}\right)\right.}{5,34}
$$

Keterangan :

$$
\begin{aligned}
\mathrm{PC}= & \text { konsentrasi fikosianin }(\mathrm{mg} / \mathrm{mL}) \\
\mathrm{OD}_{615}= & \text { Nilai absorbansi pada panjang } \\
& \text { gelombang } 615 \mathrm{~nm}\left(\lambda_{\max } \text { fikosianin }\right) \\
\mathrm{OD}_{652}= & \text { Nilai absorbansi pada panjang } \\
& \text { gelombang } 652 \mathrm{~nm}\left(\lambda_{\max } \text { allofikosianin }\right)
\end{aligned}
$$

\section{Hasil dan Pembahasan}

\section{Karakterisasi Air Limbah}

Air limbah terolah dan air limbah dari unit wet scrubber memiliki $\mathrm{pH}$ yang berbeda (Tabel 2). 
Air limbah terolah memiliki $\mathrm{pH}$ netral, sedangkan air limbah wet scrubber bersifat asam yang disebabkan oleh adanya kandungan asam yang berasal dari pelarutan gas $\mathrm{NO}_{\mathrm{x}}$ dan $\mathrm{SO}_{\mathrm{x}}$ (Jo et al., 2015). Dari segi nilai $\mathrm{pH}$, kedua air limbah tersebut tidak berada pada rentang $\mathrm{pH}$ yang optimum bagi pertumbuhan $S$. platensis yang berkisar pada pH 8,5-9,5 (Soong, 1980; Utomo et al., 2005). Namun bila dibandingkan air limbah terolah, rendahnya nila $\mathrm{pH}$ air limbah wet scrubber berpotensi untuk menghambat pertumbuhan $S$. platensis karena pada $\mathrm{pH}$ media kurang dari 7, sel $S$. platensis akan lisis dan terjadi perubahan bentuk pertumbuhan pigmen (Hariyati, 2008). Untuk mengantisipasi hal tersebut, perlu adanya pengkondisian $\mathrm{pH}$ air limbah terutama air limbah wet scrubber dengan penambahan basa ketika akan digunakan sebagai media pertumbuhan $S$. platensis.

Baik air limbah terolah maupun air limbah wet scrubber memiliki kandungan BOD dan COD yang rendah dimana kandungan COD dan BOD pada air limbah terolah sedikit lebih tinggi dibandingkan pada air limbah wet scrubber. Nilai BOD biasanya digunakan sebagai dasar untuk mengukur kandungan senyawa organik yang dapat terdegradasi dalam air limbah (Liu et al., 2018). Adanya kandungan organik pada air limbah terolah dan air limbah wet scrubber bisa menjadi kelebihan tersendiri apabila digunakan sebagai media pertumbuhan $S$. platensis pada media dengan penambahan sumber karbon organik (mixotrophic). Hasil penelitian yang telah dilakukan oleh Chang et al. (2013) menunjukkan bahwa penambahan sumber karbon organik dapat meningkatkan pertumbuhan dan kandungan protein $S$. platensis.

Air limbah terolah dan air limbah wet scrubber juga sama-sama mengandung senyawa nitrogen meskipun kandungannya tidak terlalu tinggi. Nitrogen pada air limbah terolah dapat berupa nitrogen organik (protein, peptida, atau materi genetik) dan nitrogen anorganik (nitrit, nitrat, asam nitrat, dan amonia) (Cai, Park and Li, 2013), sedangkan nitrogen pada air limbah wet scrubber berada dalam bentuk senyawa nitrat yang terbentuk dari $\mathrm{NO}_{\mathrm{x}}$ yang larut dalam scrubbing liquid (Jo et al., 2015). Cai, Park and Li (2013) menjelaskan bahwa alga eukariot seperti $S$. platensis hanya mengasimilasi nitrogen anorganik dalam bentuk nitrit, nitrat, dan amonia. Berdasarkan hal tersebut, meskipun kandungan nitrogen total pada kedua jenis air limbah tesebut relatif sama, air limbah wet scrubber berpotensi untuk lebih banyak menyediakan sumber nitrogen bagi pertumbuhan $S$. platensis karena nitrogen yang terkandung di dalamnya sebagian besar berada dalam bentuk senyawa nitrat.

Air limbah wet scrubber juga mengandung senyawa sulfat yang berasal dari $\mathrm{SO}_{x}$ yang larut dalam scrubbing liquid (Jo et al., 2015). Meskipun kandungannya relatif rendah, senyawa sulfat dalam air limbah wet scrubber berpotensi untuk menghambat pertumbuhan $S$. platensis. Hasil penelitian yang telah dilakukan oleh Kebede (1997) menunjukkan bahwa meskipun $S$. platensis memiliki toleransi yang baik terhadap ion sulfat dalam konsentrasi tinggi, laju pertumbuhan $S$. platensis dapat mengalami penurunan. Kelebihan lain dari air limbah terolah adalah adanya senyawa fosfat yang terkandung di dalamnya. Senyawa fosfor terutama dalam bentuk fosfat memiliki peranan yang sangat penting dalam pertumbuhan mikroalga (Cai, Park and Li, 2013). Çelekli, Yavuzatmaca and Bozkurt (2009) juga menjelaskan bahwa fosfat memiliki peranan yang signifikan terhadap produktivitas biomassa $S$. platensis.

Tabel 2. Hasil Karakterisasi Air Limbah Terolah dan Air Limbah Wet Srubber Industri Kertas

\begin{tabular}{clccc}
\hline No. & Parameter & Satuan & $\begin{array}{c}\text { Air } \\
\text { Limbah } \\
\text { Terolah }\end{array}$ & $\begin{array}{c}\text { Air Limbah } \\
\text { Wet } \\
\text { Scrubber }^{*}\end{array}$ \\
\hline 1 & $\mathrm{pH}$ & - & 7,8 & 4,3 \\
2 & $\mathrm{BOD}$ & $\mathrm{mg} / \mathrm{L}$ & 20 & 14 \\
3 & $\mathrm{COD}$ & $\mathrm{mg} / \mathrm{L}$ & 53 & 23 \\
4 & Nitrogen & $\mathrm{mg} / \mathrm{L}$ & 2,46 & 2,74 \\
& total & & & - \\
5 & Fosfor (P) & $\mathrm{mg} / \mathrm{L}$ & 0,94 & - \\
6 & Sulfat & $\mathrm{mg} / \mathrm{L}$ & - & 84,9 \\
\hline
\end{tabular}

*Khairunnissa et al. (2018)

\section{Pengaruh Variasi Komposisi Media dan Fotoperiode terhadap Pertumbuhan S. platensis}

Terdapat perbedaan pola $\mathrm{pH}$ kultur $S$. platensis antara yang ditumbuhkan pada kondisi fotoperiode 24 jam terang dengan kondisi fotoperiode 12jamterang/12 jamgelap(Gambar1). Pada kedua kondisi fotoperiode tersebut, $\mathrm{pH}$ awal semua komposisi media relatif sama berkisar 


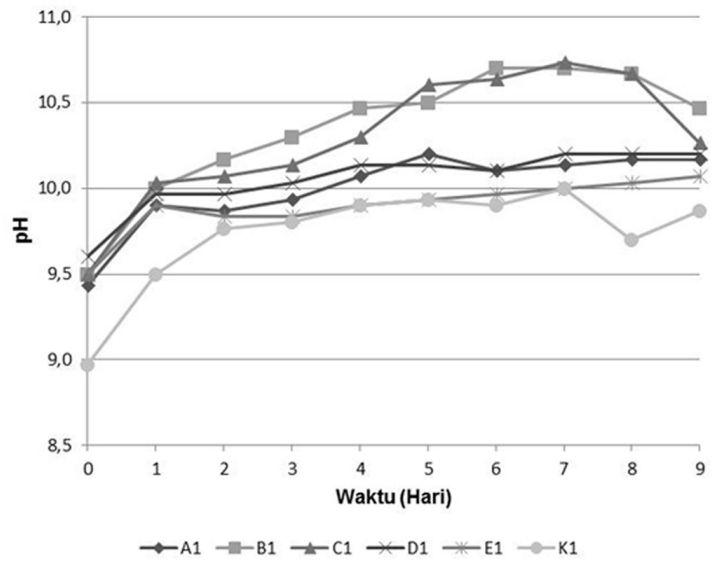

(a)

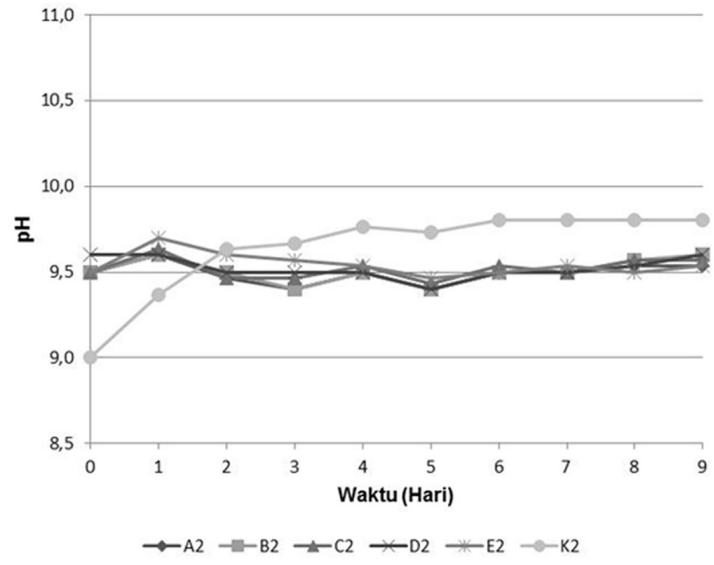

(b)

Gambar 1. Nilai pH Kultur S. platensis pada berbagai Variasi Komposisi Media dengan Perlakuan Fotoperiode 24 Jam Terang (a) dan 12 Jam Terang/12 Gelap (b)

antara 9,4-9,6 meskipun air limbah terolah dan air limbah wet scrubber memiliki pH di bawah 9. Hal ini dapat disebabkan oleh penambahan kultur S. platensis yang ditambahkan ke dalam media memiliki $\mathrm{pH}$ yang tinggi sekitar 10-11. Nilai $\mathrm{pH}$ media pada awal percobaan (hari ke-0) yang relatif sama untuk setiap komposisi air limbah menunjukkan bahwa perbedaan komposisi air limbah terolah dan air limbah wet scrubber tidak mengakibatkan perbedaan $\mathrm{pH}$ yang berarti.

Pada fotoperiode 24 jam, terjadi kenaikan $\mathrm{pH}$ media sampai 10,70 sedangkan pada fotoperiode 12 jam terang dan 12 gelap, $\mathrm{pH}$ media cenderung tidak mengalami kenaikan yang berarti dan berada pada rentang 9,6-9,8. Meskipun terjadi kenaikan $\mathrm{pH}$ media pada fotoperiode 24 jam terang, rentang $\mathrm{pH}$ media tersebut masih berada pada rentang $\mathrm{pH}$ yang optimum bagi pertumbuhan S. platensis. Hariyati (2008) menjelaskan bahwa pada umumnya mikroalga $S$. platensis tumbuh baik pada $\mathrm{pH}$ netral dan lebih mentolerir kondisi basa dari pada kondisi asam. Lebih lanjut dijelaskan pula bahwa pada $\mathrm{pH}$ media di atas 10 atau kurang dari 7 pertumbuhan S. platensis akan terhambat di mana akan terjadi perubahan bentuk pertumbuhan pigmen dan sel lisis.

Pada perlakuan fotoperiode 24 jam terang, $\mathrm{pH}$ media naik sampai hari ke-5 (perlakuan A1 dan D1) atau hari ke-7 (perlakuan B1, C1, dan E1) dan selanjutnya $\mathrm{pH}$ media cenderung tetap atau turun. Dianursanti dan Wijanarko (2007) menjelaskan bahwa kenaikan $\mathrm{pH}$ media dapat disebabkan oleh adanya kenaikan konsentrasi ion hidroksida yang dihasilkan dari proses fotosintesis oleh $S$. platensis seperti yang ditunjukkan pada persamaan 6 .

$\mathrm{H}_{2} \mathrm{O}+\mathrm{HCO}_{3}^{-} \rightarrow \mathrm{C}_{6} \mathrm{H}_{12} \mathrm{O}_{6}+\mathrm{O}_{2}+\mathrm{OH}^{-}$

Hal itu senada dengan penjelasan Chang et al., (2013) dimana $\mathrm{pH}$ media naik seiring dengan peningkatan proses fotosintesis yang dilakukan oleh $S$. platensis. Berdasarkan penjelasan tersebut, $\mathrm{pH}$ media akan naik seiring dengan semakin tingginya pertumbuhan $S$. platensis dimana pertumbuhan $S$. platensis sangat dipengaruhi oleh intensitas cahaya yang diperlukan pada proses fotosintesis (Ajayan, Selvaraju and Thirugnanamoorthy, 2012). Nilai $\mathrm{pH}$ media yang tidak terus naik setelah hari ke-5 atau hari ke-7 dapat disebabkan oleh adanya sistem penyangga (buffer) alami dari gas $\mathrm{CO}_{2}$ yang terlarut pada media dimana gas $\mathrm{CO}_{2}$ tersebut akan menjadi asam karbonat yang akan terurai menjadi ion-ion karbonat dan ion bikarbonat (Amanatin and Nurhidayati, 2013). Pada perlakuan fotoperiode $12 \mathrm{jam}$ terang/12 jam gelap, $\mathrm{pH}$ media tidak mengalami kenaikan yang signifikan kecuali kontrol. Hal ini menunjukkan bahwa perbedaan perlakuan fotoperiode dapat mempengaruhi pertumbuhan $S$. platensis dan secara tidak langsung dapat mempengaruhi nilai $\mathrm{pH}$ media yang digunakan untuk pertumbuhan S. platensis. 
Pada kondisi fotoperiode yang sama, pertumbuhan S. platensis relatif sama pada semua komposisi media yang diujicobakan, namun pertumbuhan S. platensis berbeda antara perlakuan fotoperiode 24 jam terang dengan fotoperiode 12 jam terang/12 jam gelap (Gambar 2a dan Gambar 2b). Hasil uji statistik analisis variansi (ANOVA) dengan tingkat kepercayaan 95\% menunjukkan bahwa variasi komposisi media tidak berpengaruh nyata terhadap konsentrasi biomassa $S$. platensis (sig. $>0,05$ ) tetapi fotoperiode berpengaruh nyata terhadap konsentrasibiomassa S. platensis (sig. $<0,05$ ). Pada perlakuan fotoperiode 24 jam terang, konsentrasi biomassa $S$. platensis bertambah seiring dengan bertambahnya waktu pertumbuhan sampai hari ke-5 kemudian konsentrasi biomassa relatif tidak berubah bahkan mengalami penurunan sampai

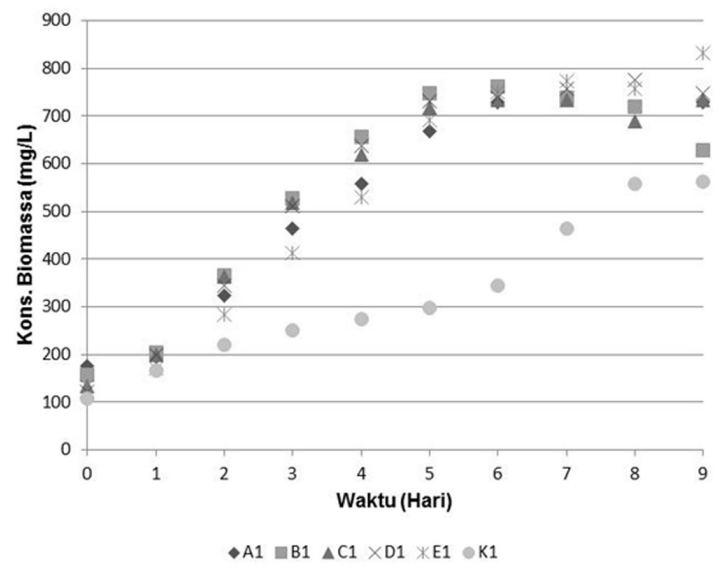

(a)

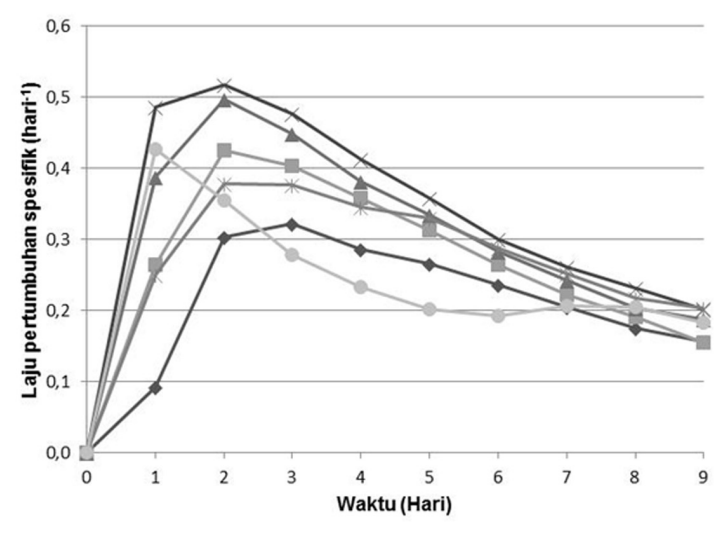

$\rightarrow \mathrm{A} 1 \rightarrow-\mathrm{B} 1 \multimap \mathrm{C} 1 \multimap \mathrm{D} 1 \div \mathrm{E} 1 \rightarrow \mathrm{K} 1$

(c) akhir percobaan atau hari ke-9. Berbeda halnya pada perlakuan fotoperiode $12 \mathrm{jam}$ terang/12 jam gelap dimana konsentrasi biomassa $S$. platensis turun pada hari pertama untuk setiap perlakuan variasi komposisi media kecuali media D (25\% air limbah terolah, 75\% air limbah wet scrubber) dan kontrol. Kenaikan konsentrasi biomassa baru terjadi setelah hari ke-2 sampai akhir percobaan (hari ke-9) kecuali kontrol.

Laju pertumbuhan spesifik $S$. platensis berbeda-beda untuk setiap komposisi media dimana secara umum laju pertumbuhan spesifik pada fotoperiode 24 jam terang jauh lebih tinggi dibandingkan pada fotoperiode 12 jam terang/12 jam gelap (Gambar 2c dan Gambar 2d). Hal ini senada dengan hasil penelitian yang telah dilakukan oleh Budiardi, Utomo dan Santosa (2010) dimana laju pertumbuhan S. platensis

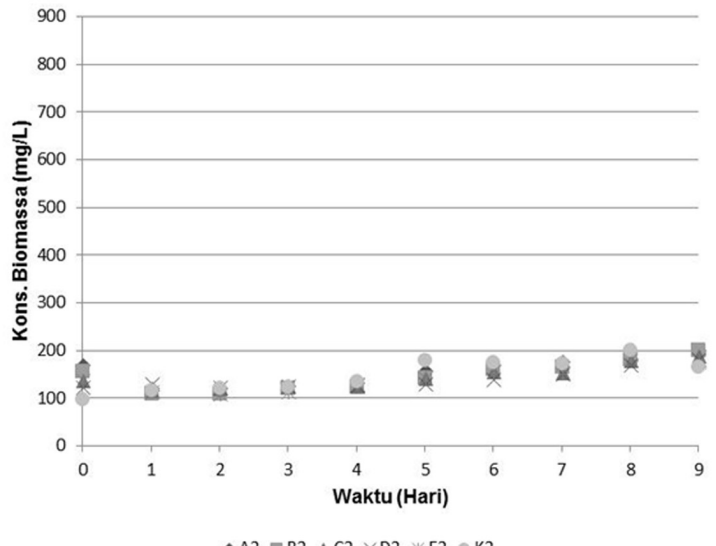

(b)

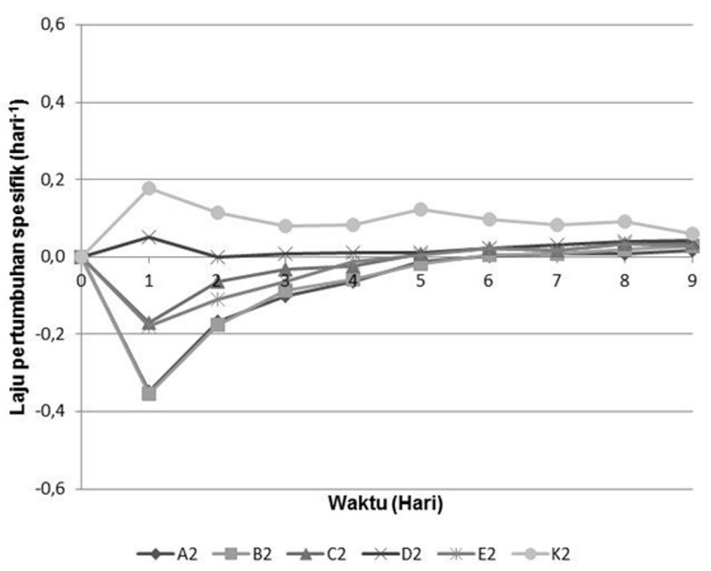

(d)

Gambar 2. Konsentrasi Biomassa dan Laju Pertumbuhan Spesifik S. platensis pada berbagai Variasi Komposisi Media dengan Perlakuan Fotoperiode 24 Jam Terang (a, c) dan 12 Jam Terang/12 Jam Gelap (b, d) 
pada fotoperiode 24 jam terang lebih tinggi dibandingkan perlakuan dengan waktu terang yang lebih singkat meskipun media pertumbuhannya sama. Laju pertumbuhan spesifik $S$. platensis pada media D (25\% air limbah terolah dan $75 \%$ air limbah wet scrubber) lebih tinggi dibandingkan perlakuan media lainnya baik pada perlakuan fotoperiode 24 jam terang maupun fotoperiode 12 jam terang/12 jam gelap. Laju pertumbuhan spesifik tertinggi untuk setiap komposisi media kecuali kontrol terjadi pada hari ke-2 (fotoperiode 24 jam terang) dan hari ke-1 (fotoperiode 12 jam terang/12 jam gelap), selanjutnya laju pertumbuhan spesifik mengalami penurunan sampai hari ke-9. Pada perlakuan fotoperiode $12 \mathrm{jam}$ terang/12 jam gelap, laju pertumbuhan spesifik bernilai negatif pada 5 hari pertama pertumbuhan yang menunjukan terjadinya penurunan konsentrasi biomassa S. platensis dan baru bernilai positif pada hari ke-6 dan meningkat sampai hari ke-9. Hal ini terjadi hampir pada setiap perlakuan media kecuali perlakuan media D (25\% air limbah terolah, $75 \%$ air limbah wet scrubber) dan kontrol.

Perbedaan pola pertumbuhan $S$. platensis antara perlakuan fotoperiode 24 jam terang dengan fotoperiode 12 jam terang/12 jam gelap dapat menunjukkan perbedaan fase pertumbuhan S. platensis pada kedua perlakuan fotoperiode tersebut. Pada perlakuan fotoperiode 24 jam terang, S. platensis dapat langsung memasuki fase pertumbuhan (eksponensial) dengan waktu adaptasi yang sangat singkat. Meskipun pada hari pertama sudah terjadi peningkatan konsentrasi biomassa, bukan berarti $S$. platensis tidak melalui fase adaptasi (lag) karena fase adaptasi dapat berlangsung cepat sehingga sulit untuk diamati (Budiardi, Utomo and Santosa, 2010). Pada penelitian yang dilakukan oleh Çelekli, Yavuzatmaca dan Bozkurt (2009), fase lag atau adaptasi terjadi hanya selama 4 jam selanjutnya biomassaS. platensisnaiksecaratajam. Singkatnya fase lag dapat terjadi karena inokulum yang digunakan diambil ketika masih berada dalam fase $\log$ /eksponensial seperti pada penelitian yang dilakukan oleh Rodrigues et al. (2010). Pertambahan konsentrasi biomassa $S$. platensis mulai relatif sama atau turun (fase stasioner) pada hari ke-5 kecuali kontrol pada hari ke-8. Sebaliknya, pada perlakuan fotoperiode 12 jam terang/12 jam gelap, $S$. platensis mengalami fase adaptasi yang cukup lama sampai 5 hari kemudian memasuki fase pertumbuhan dan belum memasuki fase stasioner sampai akhir percobaan (hari ke-9). Çelekli, Yavuzatmaca dan Bozkurt (2009) menjelaskan bahwa fase lag terjadi karena proses penyesuaian $S$. platensis. Berdasarkan data pada Gambar 2, dapat dikatakan bahwa $S$. platensis lebih mudah beradaptasi dengan media pertumbuhan yang baru (air limbah terolah dan air limbah wet scrubber) dibandingkan kondisi pencahayaan dari fotoperiode 24 jam ketika perbanyakan menjadi 12 jam terang/12 jam gelap saat percobaan.

Perbedaan pola pertumbuhan $S$. platensis antara perlakuan fotoperiode 24 jam terang dengan fotoperiode $12 \mathrm{jam}$ terang/12 jam gelap juga dapat menunjukkan bahwa cahaya merupakan faktor yang sangat mempengaruhi pertumbuhan $S$. platensis dimana semakin lama periode pencahayaan, konsentrasi biomassa $S$. platensis semakin tinggi. Hal ini sejalan dengan hasil penelitian yang telah dilakukan oleh Endrawati, Manulang dan Widianingsih (2012) yang menunjukkan bahwa kepadatan sel S. platensis tertinggi diperoleh pada perlakukan dengan lama pencahayaan (fotoperiode) 24 jam dibandingkan perlakuan dengan pencahayaan yang lebih singkat. Lebih lanjut dijelaskan bahwa hal itu terjadi karena energi cahaya sangat berperan dalam proses fotosintesis untuk pembentukan energi yang akan digunakan untuk pertumbuhan. Semakin lama periode pencahayaan, semakin banyak energi yang dapat digunakan untuk proses fotosintesis sehingga semakin banyak pula energi yang dapat digunakan untuk pertumbuhan dan sebaliknya. Ajayan, Selvaraju dan Thirugnanamoorthy (2012) juga menjelaskan bahwa dengan intensitas cahaya yang tinggi, semakin banyak energi listrik yang diperoleh yang sangat menguntungkan untuk pertumbuhan sel dan produksi biokimia. Selain itu, lamanya waku pencahayaan juga berpengaruh terhadap konsumsi nutrien pada media dimana waktu pencahayaan yang terlalu singkat dapat mempengaruhi pemanfaatan nitrat dan fosfat dalam media (Meseck, Alix and Wikfors, 2005).

Pada perlakuan fotoperiode 24 jam terang, kenaikan konsentrasi biomassa $S$. platensis terjadi hanya sampai hari ke-5 dan selanjutnya konsentrasi biomassa cenderung sama atau bahkan menurun untuk setiap perlakuan kecuali kontrol yang masih mengalami kenaikan sampai hari ke-8. Ada beberapa faktor yang dapat menyebabkan hal itu terjadi diantaranya, yaitu ketersediaan hara dan pengaruh intensitas cahaya. Budiardi, 
Utomo, dan Santosa, (2010) menjelaskan bahwa penurunan konsentrasi bomassa dapat terjadi karena penurunan kandungan nutrisi dan akibat pebentukan bayangan dari sel itu sendiri (self shading effect) karena kepadatan sel $S$. platensis yang sudah cukup tinggi. Lebih lanjut dijelaskan bahwa efek ini berjalan seiring dengan semakin meningkatnya kepadatan sel dimana cahaya akan semakin sulit untuk masuk ke dalam kultur. Kultur S. platensis yang terlalu padat mengakibatkan intensitas cahaya tidak terdistribusi secara merata sehingga ada bagian kultur yang tidak mendapatkan cahaya yang cukup untuk menunjang pertumbuhannya (Dianursanti dan Wijanarko, 2007).

Pada perlakuan fotoperiode 12 jam terang/ 12 jam gelap, meskipun terjadi penurunan konsentrasi biomassa $S$. platensis pada 5 hari pertama, konsentrasi biomassa $S$. platensis terus naik dan tidak teramati adanya penurunan konsentrasi biomassa $S$. platensis sampai akhir percobaan (hari ke-9). Hal itu terjadi karena laju pertumbuhan $S$. platensis yang jauh lebih rendah dibandingkan pada kondisi fotoperiode 24 jam terang. Selain itu, pada waktu pencahayaan yang lebih singkat, konsumsi nitrat dan fosfat dalam media tidak setinggi pada fotoperiode 24 jam terang (Meseck, Alix and Wikfors, 2005) sehingga dengan jumlah nutrisi yang sama, konsumsi nutrisi yang lebih rendah mengakibatkan masih tersedianya nutrisi pada media yang menunjang pertumbuhan $S$. platensis sampai akhir percobaan (hari ke-9).
Konsentrasi biomassa $S$. platensis tertinggi diperoleh pada perlakuan E1 sebesar $831 \mathrm{mg} / \mathrm{L}$ lebih tinggi 47\% dibandingkan kontrol namun pertumbuhan terbaik diperoleh pada perlakuan D1 dengan laju pertumbuhan spesifik 0,52 hari $^{-1}$ dan waktu penggandaan 0,4 hari (Tabel 3). Laju pertumbuhan spesifik hasil penelitian lebih tinggi dibandingkan hasil penelitian Budiardi, Utomo dan Santosa (2010), yaitu sebesar 0,366 hari $^{-1}$ denganmengunakanmediayang terbuatdaripupuk komersial dan hasil penelitian Chang et al. (2013), yaitu 0,292 hari $^{-1}$ yang menggunkan media urin manusia sintetik yang ditambahkan $200 \mathrm{mg} / \mathrm{L}$ natrium asetat. Waktu penggandaan $S$. platensis hasil penelitian juga lebih singkat dibandingkan hasil penelitian yang telah dilakukan oleh Budiardi, Utomo dan Santosa (2010), yaitu sebesar 1,89 hari. Berdasarkan hal tersebut, air limbah terolah dan air limbah wet scrubber memiliki potensi yang cukup besar sebagai media pertumbuhan $S$. platensis seperti media-media alternatif yang pernah diteliti sebelumnya.

Konsentrasi biomassa $S$. platensis hasil penelitian lebih tinggi dibandingkan penelitian sebelumnya yang menggunakan 100\% air limbah terolah, yaitu $395 \mathrm{mg} / \mathrm{L}$ (Asthary et al., 2013) dan hasil penelitian yang telah dilakukan oleh Khairunnissa et al. (2018), yaitu $813 \mathrm{mg} / \mathrm{L}$ yang menggunakan media dari air limbah wet scrubber dan media Zarrouk dengan komposisi 75\%:25\%. Pada kondisi fotoperiode 12 jam terang/12 jam gelap, konsentrasi biomassa S. platensis tertinggi sebesar $201 \mathrm{mg} / \mathrm{L}$ diperoleh

Tabel 3. Pertumbuhan dan Kandungan Fikosianin S. platensis pada berbagai Komposisi Media dan Kondisi Fotoperiode

\begin{tabular}{|c|c|c|c|c|c|c|c|c|c|c|c|c|}
\hline & \multicolumn{6}{|c|}{24 Jam Terang } & \multicolumn{6}{|c|}{12 Jam Terang/12 Jam Gelap } \\
\hline & A1 & B1 & $\mathrm{C} 1$ & D1 & E1 & K1 & $\mathrm{A} 2$ & B2 & $\mathrm{C} 2$ & $\mathrm{D} 2$ & E2 & $\mathrm{K} 2$ \\
\hline $\begin{array}{l}\text { Biomassa }(\mathrm{mg} / \mathrm{L}) \\
\text { Produktivitas }\end{array}$ & 741 & 762 & 733 & 775 & 831 & 563 & 198 & 201 & 188 & 181 & 180 & 202 \\
\hline $\begin{array}{l}\text { Biomassa (mg/L. } \\
\text { hari) }\end{array}$ & 98 & 125 & 128 & 129 & 111 & 58 & 3 & 5 & 6 & 7 & 6 & 19 \\
\hline $\begin{array}{l}\text { Laju Pertumbuhan } \\
\text { Spesifik }\left(\text { hari }^{-1}\right)\end{array}$ & 0,32 & 0,43 & 0,50 & 0,52 & 0,38 & 0,43 & 0,02 & 0,03 & 0,04 & 0,05 & 0,04 & 0,18 \\
\hline $\begin{array}{l}\text { Waktu Penggandaan } \\
\text { (hari) }\end{array}$ & 0,5 & 0,4 & 0,4 & 0,4 & 0,4 & 0,4 & 4,8 & 3,0 & 2,2 & 1,9 & 2,5 & 1,0 \\
\hline $\begin{array}{l}\text { Konsentrasi } \\
\text { Fikosianin (mg/L) }\end{array}$ & 0,26 & 0,22 & 0,27 & 0,23 & 0,21 & 0,11 & 0,08 & 0,09 & 0,09 & 0,08 & 0,08 & 0,04 \\
\hline $\begin{array}{l}\text { Kandungan } \\
\text { Fikosianin (mg/g) }\end{array}$ & 0,36 & 0,29 & 0,37 & 0,33 & 0,38 & 0,27 & 0,47 & 0,45 & 0,51 & 0,47 & 0,48 & 0,30 \\
\hline
\end{tabular}


pada media B2 $(75 \%$ air limbah terolah dan $25 \%$ air limbah wet scrubber), sedikit lebih rendah dibandingkan hasil penelitian yang telah dilakukan oleh Setiawan et al. (2014), yaitu $222 \mathrm{mg} / \mathrm{L}$ yang menggunkan media dari air limbah terolah dengan pencahayaan selama 12 jam dan menggunakan emisi dari boiler sebagai sumber $\mathrm{CO}_{2}$. Berdasarkan penelitian-penelitian sebelumnya tersebut dan data pada Tabel 3, dapat dikatakan bahwa konsentrasi biomassa S. platensis cenderung lebih tinggi pada media yang lebih banyak mengandung air limbah wet scrubber dibandingkan air limbah terolah pada kondisi fotoperiode 24 jam terang. Hal itu dapat disebabkan karena perbedaan senyawa nitrogen yang terdapat dalam kedua air limbah tersebut. Nitrogen sangat penting bagi pertumbuhan $S$. platensis mengingat nitrogen merupakan elemen kedua terbanyak yang terkandung dalam S. platensis (Rodrigues et al., 2010) dan alga eukariot seperti $S$. platensis hanya mengasimilasi nitrogen anorganik dalam bentuk nitrit, nitrat, dan amonia (Cai, Park and Li, 2013). Dengan kandungan nitrogen total yang relatif sama, air limbah wet scrubber yang kandungan senyawa nitrogennya sebagian besar berada dalam bentuk senyawa nitrat (Jo et al., 2015) berpotensi untuk lebih banyak menyediakan sumber nitrogen bagi pertumbuhan $S$. platensis dibandingkan air limbah terolah dengan senyawa nitrogen yang terkandung di dalamnya tidak hanya berupa nitrogen anorganik (nitrit, nitrat, asam nitrat, dan amonia), tetapi dapat juga berupa nitrogen organik (protein, peptida, atau materi genetik) (Cai, Park and Li, 2013).

Konsentrasi fikosianin pada semua komposisi media tidak lebih rendah dibandingkan kontrol. Hal ini menunjukkan bahwa air limbah terolah dan air limbah wet scrubber tidak berpengaruh negatif terhadap kandungan fikosianin pada $S$. platensis namun konsentrasi fikosianin pada kultur S. platensis dipengaruhi oleh fotoperiode dimana konsentrasi fikosianin pada fotoperiode 24 jam terang relatif lebih tinggi dibandingkan pada fotoperiode 12jamterang/12jamgelap(Gambar3). Pada perlakuan fotoperiode 24 jam terang, konsentrasi fikosianin pada kultur S. platensis naik sampai hari ke-6 yang menjadi puncaknya kemudian mengalami penurunan sampai hari ke-9. Berbeda dengan perlakuan fotoperiode 12 jam terang/12 jam gelap dimana konsentrasi fikosianin pada kultur $S$. platensis baru mengalami kenaikan setelah hari ke-6 dengan kenaikan yang tidak setinggi pada perlakuan fotoperode 24 jam terang. Baik pada perlakuan fotoperiode 24 jam terang maupun 12 jam terang/12 jam gelap, pola kenaikan kandungan fikosianin dalam kultur $S$. platensis mirip dengan pola kenaikan konsentrasi biomassa S. platensis. Salah satu perbedaannya terletak pada konsentrasi fikosianin yang cenderung turun pada hari ke-6 sampai hari ke-9 meskipun konsentrasi biomassa cenderung tetap. Hasil penelitian Allen dan Smith (1969) menunjukkan adanya hubungan antara kekurangan (defisiensi) sumber nitrogen dengan turunnya kandungan fikosianin pada beberapa strain alga biru-hijau
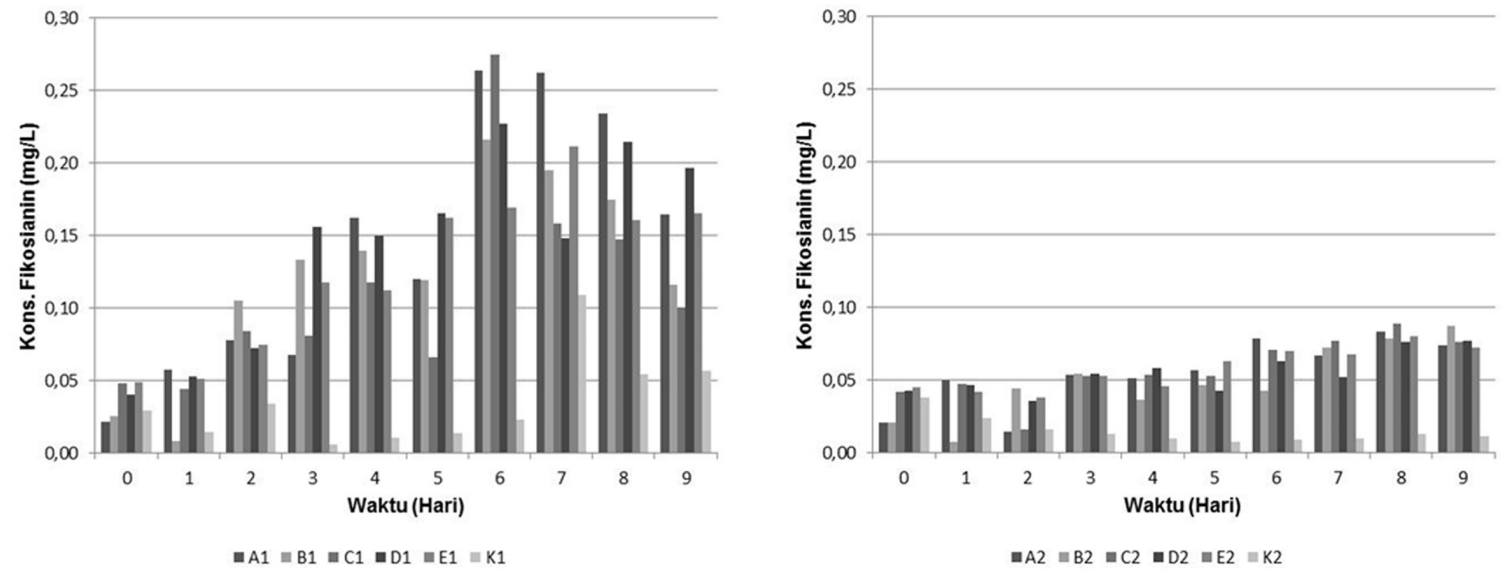

Gambar 3. Konsentrasi Fikosianin S. platensis pada berbagai Variasi Komposisi Media dengan Perlakuan Fotoperiode 24 Jam Terang (a) dan 12 Jam Terang/12 Gelap (b) 
(nitrogen chlorosis). Boussiba dan Richmond (1980) juga menjelaskan bahwa fikosianin dapat menjadi sumber nitrogen bagi S. platensis ketika terjadi penurunan ketersediaan nitrogen pada media (nitrogen starvation) dimana pada kondisi tersebutkandungan fikosianin menurun tetapi tidak mempengaruhi laju pertumbuhan $S$. platensis. Hasil penelitian yang dilakukan oleh Eriksen (2008) juga menunjukkan bahwa kandungan fikosianin dipengaruhi oleh konsentrasi sumber nitrogen yang tersedia pada media kultur dimana kandungan fikosianin yang maksimum terjadi sesaat sebelum media kultur kehabisan sumber nitrogen dan turun secara drastis setelah sumber nitrogen tidak lagi tersedia pada media kultur. Hal itu terjadi karena pada saat sumber nitrogen pada media kultur semakin berkurang, fikosianin akan terdegradasi dan menjadi sumber nitrogen bagi $S$. platensis (Chen et al., 2013).

Kandungan fioksianin per massa kering S. platensis pada perlakuan fotoperiode 12 jam terang/12 jam gelap relatif lebih tinggi dibandingkan pada perlakuan fotoperiode 24 jam terang meskipun konsentrasi fikosianin dalam kultur jauh lebih rendah (Tabel 3). Pada kondisi dengan pencahayaan yang kurang, S. platensis cenderung untuk menyimpan energinya dalam bentuk lipid dibandingkan untuk memperbanyak sel sebagai bentuk adaptasi $S$. platensis dalam mempertahankan hidup terhadap kondisi lingkungan yang ekstrim atau pada keadaan di luar kondisi optimal untuk tumbuh(Schenk et al.,2008; Endrawati, Manulang and Widianingsih, 2012). Selain itu, Budiardi, Utomo dan Santosa (2010) menjelaskan bahwa penurunan intensitas cahaya dapat mengakibatkan peningkatan pigmenpigmen yang berfungsi untuk menangkap cahaya termasuk pigmen fikosianin.

Berdasarkan data pertumbuhan dan kandungan fikosianin pada $S$. platensis yang diperoleh dari hasil penelitian, air limbah terolah dan air limbah wet scrubber memiliki potensi sebagai media alternatif untuk pertumbuhan $S$. platensis pada semua komposisi yang telah diujicobakan. Biomassa S. platensis yang dihasilkan juga lebih tinggi dibandingkan hasil penelitian sebelumnya yang dapat dimanfaatkan lebih lanjut baik untuk keperluan di bidang akuakultur atau pakan maupun sebagai bahan baku energi terbarukan. Namun dari hasil penelitian juga dapat diketahui bahwa lamanya pencahayaan (fotoperiode) sangat berpengaruh terhadap pertumbuhan S. platensis dimana dengan media yang sama, pertumbuhan
S. platensis jauh lebih rendah pada fotoperiode 12 jam terang/12 gelap dibandingkan pada fotoperiode 24 jam terang karena pencahayaan selama 12 jam belum bisa menyediakan energi yang cukup untuk pertumbuhan $S$. platensis yang optimal. Sehingga untuk aplikasi dalam sekala lapangan perlu adanya rekayasa untuk mengoptimalkan pencahayaan untuk pertumbuhan $S$. platensis meskipun lamanya periode pencahayaan tidak sampai 24 jam atau mengikuti siklus normal siang dan malam.

\section{Kesimpulan}

S. platensis dapat tumbuh dengan baik pada semua komposisi air limbah terolah dan air limbah dari proses wet scrubber industri kertas yang telah diujicobakan. Komposisi kedua air limbah tersebut tidak berpengaruh nyata terhadap konsentrasi biomassa $S$. platensis namun perbedaan waktu pencahayaan (fotoperiode) sangat berpengaruh terhadap konsentrasi biomassa $S$. platensis. Konsentrasi biomasa tertinggi sebesar $831 \mathrm{mg} / \mathrm{L}$ dan laju pertumbuhan spesifik tertinggi sebesar 0,52 hari $^{-1}$ dengan waktu penggandaan 0,4 hari diperoleh pada perlakuan fotoperiode 24 jam terang. Kandungan fikosianin tertinggi sebesar $0,48 \mathrm{mg} / \mathrm{g}$ diperoleh pada perlakuan fotoperiode 12 jam terang/12 jam gelap.

\section{Daftar Pustaka}

Ajayan, K. V., Selvaraju, M. and Thirugnanamoorthy, K. (2012) 'Enrichment of chlorophyll and phycobiliproteins in Spirulina platensis by the use of reflector light and nitrogen sources: An in-vitro study', Biomass and Bioenergy, 47, pp. 436441. doi: 10.1016/j.biombioe.2012.09.012.

Allen, M. M. and Smith, A. J. (1969) 'Nitrogen chlorosis in blue-green algae', Arch. Mikrobiol., 69(2), pp. 114-120. doi: 10.1007/BF00409755.

Amanatin, D. R. and Nurhidayati, T. (2013) 'Pengaruh Kombinasi Konsentrasi Media Ekstrak Tauge (MET) dengan Pupuk Urea terhadap Kadar Protein Spirulina sp', Jurnal Sains dan Seni ITS, 2(2), pp. E182-E1885. doi: 10.12962/j23373520.v2i2.4054.

Ashrafi, O., Yerushalmi, L. and Haghighat, F. (2015) 'Wastewater treatment in the pulpand-paper industry: A review of treatment processes and the associated greenhouse gas emission', Journal of Environmental Management, 158, pp. 146-157. doi: 10.1016/j.jenvman.2015.05.010. 
Asthary, P. B. et al. (2013) 'Pertumbuhan Mikroalga Spirulina platensis dalam Efluen Industri Kertas', Jurnal Selulosa, 3(2), pp. 97-102.

Bennet, A. and Bogorad, L. (1973) 'Complementary Cromatic Adaptation in A Filamentous Blue-Green Alga', The Journal of Cell Biology, 58, pp. 419-435. doi: 10.1016/S0022-3468(89)80710-9.

Bermejo, P., Piñero, E. and Villar, Á. M. (2008) 'Iron-chelating ability and antioxidant properties of phycocyanin isolated from a protean extract of Spirulina platensis', Food Chemistry, 110(2), pp. 436-445. doi: 10.1016/j.foodchem.2008.02.021.

Bertolin, T. E. et al. (2011) 'Antioxidant Effect of Phycocyanin on Oxidative Stress Induced with Monosodium Glutamate in Rats', Brazilian Archives of Biology and Technology, 54(4), pp. 733-738. doi: 10.1590/s1516-89132011000400012.

Bezerra, R. P. et al. (2012) 'Effects of photobioreactor configuration, nitrogen source and light intensity on the fed-batch cultivation of Arthrospira (Spirulina) platensis. Bioenergetic aspects', Biomass and Bioenergy, 37, pp. 309-317. doi: 10.1016/j. biombioe.2011.11.007.

Blinkova, L. P., Gorobets, O. B. and Baturo, A. P. (2001) 'Biological activity of Spirulina', Zhurnal mikrobiologii, epidemiologii, $i$ immunobiologii, (2), pp. 114-118.

Boussiba, S. and Richmond, A. E. (1980) 'C-phycocyanin as a storage protein in the blue-green alga Spirulina platensis', Archives of Microbiology, 125(1-2), pp. 143-147. doi: 10.1007/BF00403211.

Braga, V. da S. et al. (2018) 'Cultivation strategy to stimulate high carbohydrate content in Spirulina biomass', Bioresource Technology, 269(August), pp. 221-226. doi: 10.1016/j. biortech.2018.08.105.

Braga, V. da S. et al. (2019) 'Enhancement of the carbohydrate content in Spirulina by applying $\mathrm{CO} 2$, thermoelectric fly ashes and reduced nitrogen supply', International Journal of Biological Macromolecules, 123, pp. 12411247. doi: 10.1016/j.ijbiomac.2018.12.037.

Budiardi, T., Utomo, N. B. P. and Santosa, A. (2010) 'Pertumbuhan dan kandungan nutrisi Spirulina sp . pada fotoperiode yang berbeda', Jurnal Akuakultur Indonesia, 9(2), pp. 146-156.

Cai, T., Park, S. Y. and Li, Y. (2013) 'Nutrient recovery from wastewater streams by microalgae: Status and prospects', Renewable and Sustainable Energy Reviews, 19, pp. 360-369. doi: 10.1016/j.rser.2012.11.030.
Çelekli, A., Yavuzatmaca, M. and Bozkurt, H. (2009) 'Modeling of biomass production by Spirulina platensis as function of phosphate concentrations and $\mathrm{pH}$ regimes', Bioresource Technology, 100(14), pp. 3625-3629. doi: 10.1016/j.biortech.2009.02.055.

Chang, Y. et al. (2013) 'Cultivation of Spirulina platensis for biomass production and nutrient removal from synthetic human urine', Applied Energy, 102, pp. 427-431. doi: 10.1016/j. apenergy.2012.07.024.

Cheirsilp, B. and Torpee, S. (2012) 'Enhanced growth and lipid production of microalgae under mixotrophic culture condition: Effect of light intensity, glucose concentration and fedbatch cultivation', Bioresource Technology. Elsevier Ltd, 110, pp. 510-516. doi: 10.1016/j. biortech.2012.01.125.

Chen, C. Y. et al. (2013) 'Engineering strategies for simultaneous enhancement of C-phycocyanin production and CO2fixation with Spirulina platensis', Bioresource Technology, 145, pp. 307-312. doi: 10.1016/j.biortech.2013.01.054.

Colla, L. M. et al. (2015) 'Potential of Live Spirulina platensis on Biosorption of Hexavalent Chromium and Its Conversion to Trivalent Chromium', International Journal of Phytoremediation, 17(9), pp. 861-868. doi: 10.1080/15226514.2014.964846.

Demirbas, M. F. (2011) 'Biofuels from algae for sustainable development', Applied Energy. Elsevier Ltd, 88(10), pp. 3473-3480. doi: 10.1016/j.apenergy.2011.01.059.

Dianursanti and Wijanarko, A. (2007) 'Enhancement Of Cyanobacteria Growth In Serial Configuration Photobioreactor By Photon Flux Density Alteration', Jurnal Teknologi, (4), pp. 299-308.

Doble, M. and Kumar, A. (2005) 'CHAPTER 19 - Paper and Pulp', in Doble, M. and Kumar, A. (eds) Biotreatment of Industrial Effluents. Burlington: Butterworth-Heinemann, pp. 197-207. doi: https://doi.org/10.1016/B978075067838-4/50020-8.

Endrawati, H., Manulang, C. and Widianingsih (2012) 'Densitas dan Kadar Total Lipid Mikroalga Spirulina platensis yang Dikultur pada Fotoperioda yang Berbeda', Buletin Oseanografi Marina, 1, pp. 33-38.

Eriksen, N. T. (2008) 'Production of phycocyanin - A pigment with applications in biology, biotechnology, foods and medicine', Applied Microbiology and Biotechnology, 80(1), pp. 1-14. doi: 10.1007/s00253-008-1542-y.

Gude, V. G. (2015) 'Energy and water autarky of wastewater treatment and power generation systems', Renewable and Sustainable Energy Reviews. Elsevier, 45, pp. 52-68. doi: 10.1016/j.rser.2015.01.055. 
Gude, V. G. (2016) 'Wastewater treatment in microbial fuel cells - An overview', Journal of Cleaner Production, 122, pp. 287-307. doi: 10.1016/j.jclepro.2016.02.022.

Gude, V. G., Kokabian, B. and Gadhamshetty, V. (2013) 'Beneficial Bioelectrochemical Systems for Energy, Water, and Biomass Production', Journal of Microbial \& Biochemical Technology, S6(005). doi: 10.4172/1948-5948.s6-005.

Hariyati, R. (2008) 'Pertumbuhan dan Biomassa Spirulina sp dalam Skala Laboratoris', Bioma, 10(1), pp. 19-22.

Jo, E.etal. (2015) 'A study on the removal of sulfate and nitrate from the wet scrubber wastewater using electrocoagulation', Desalination and Water Treatment, 57(17), pp. 7833-7840. doi: 10.1080/19443994.2015.1028461.

Kebede, E. (1997) 'Response of Spirulina platensis (=Arthrospira fusiformis) from Lake Chitu, Ethiopia, to salinity stress from sodium salts', Journal of Applied Phycology, 9(6), pp. 551558. doi: 10.1023/A:1007949021786.

Khairunnissa, I. N. et al. (2018) 'Pemanfaatan Air Limbah Wet Scrubber Flue Gas Desulphurization (FGD) Industri Kertas sebagai Media Pertumbuhan Spirulina platensis', Jurnal Selulosa, 8(2), pp. 94-104.

Kim, K. et al. (2013) 'Impact of light intensity, $\mathrm{CO} 2$ concentration and bubble size on growth and fatty acid composition of Arthrospira (Spirulina) platensis KMMCC CY-007', Biomass and Bioenergy, 49, pp. 181-187. doi: 10.1016/j.biombioe.2012.12.021.

Kokabian, B. and Gude, V. G. (2015) 'Sustainable photosynthetic biocathode in microbial desalination cells', Chemical Engineering Journal. Elsevier B.V., 262, pp. 958-965. doi: 10.1016/j.cej.2014.10.048.

Kuddus, M. et al. (2013) 'Recent developments in production and biotechnological applications of c-phycocyanin', BioMed Research International, 2013, pp. 1-9. doi: 10.1155/2013/742859.

Leduy, A. and Therien, N. (1977) 'An improved method for optical density measurement of the semimicroscopic blue green alga Spirulina maxima', Biotechnology and Bioengineering, 19(8), pp. 1219-1224. doi: 10.1002/bit.260190812.

Lee, Y. K. (2004) Hand Book of Microalga Culture: Biotechnology and Applied Phycology. Edited by A. Richmond. Oxford: Blackwell Publishing.

Liu, Y. et al. (2018) 'Quantifying biodegradable organic matter in polluted water on the basis of coulombic yield', Talanta, 176, pp. 485491. doi: 10.1016/j.talanta.2017.08.029.
Manullang, C., Widianingsih and Endrawati, H. (2012) 'Densitas dan Kandungan Total Lipid Mikroalga Spirulina platensis', Journal of Marine Research, 1(1), pp. 24-28. Available at: http://ejournal-s1.undip.ac.id/index.php/jmr.

Meseck, S. L., Alix, J. H. and Wikfors, G. H. (2005) 'Photoperiod and light intensity effects on growth and utilization of nutrients by the aquaculture feed microalga, Tetraselmis chui (PLY429)', Aquaculture, 246(1-4), pp. 393-404. doi: 10.1016/j. aquaculture.2005.02.034.

Ono, E. and Cuello, J. L. (2004) 'Design parameters of solar concentrating systems for CO2-mitigating algal photobioreactors', Energy, 29(9), pp. 1651-1657.

Rajak, U. and Verma, T. N. (2018) 'Spirulina microalgae biodiesel - A novel renewable alternative energy source for compression ignition engine', Journal of Cleaner Production, 201(X), pp. 343-357. doi: 10.1016/j.jclepro.2018.08.057.

Rodrigues, M. S. et al. (2010) 'Fed-batch cultivation of Arthrospira (Spirulina) platensis: Potassium nitrate and ammonium chloride as simultaneous nitrogen sources', Bioresource Technology, 101(12), pp. 44914498. doi: 10.1016/j.biortech.2010.01.054.

Romay, C. et al. (1998) 'Antioxidant and antiinflammatory properties of C-phycocyanin from blue-green algae', Inflammation Research, 47(1), pp. 36-41. doi: 10.1007/ s000110050256.

Schenk, P. M. et al. (2008) 'Second Generation Biofuels: High-Efficiency Microalgae for Biodiesel Production', BioEnergy Research, 1(1), pp. 20-43. doi: 10.1007/s12155-008-9008-8.

Setiawan, Y. et al. (2014) 'Pemanfaatan Emisi Gas CO2 untuk Budidaya Spirulina platensis dalam Upaya Penurunan Gas Rumah Kaca (GRK)', Jurnal Riset Industri, 8(2), pp. 83-89.

Soni, R. A., Sudhakar, K. and Rana, R. S. (2017) 'Spirulina - From growth to nutritional product: A review', Trends in Food Science and Technology, 69, pp. 157-171. doi: 10.1016/j.tifs.2017.09.010.

Soong, P. (1980) 'Production and development of Chlorella and Spirulina in Taiwan.', in Shelef, G. and Soeder, C.J., pp. 97-113.

Sumprasit, N. et al. (2017) 'Biodiesel and biogas recovery from Spirulina platensis', International Biodeterioration and Biodegradation, 119, pp. 196-204. doi: 10.1016/j.ibiod.2016.11.006.

Thompson, G. et al. (2001) 'The treatment of pulp and paper mill effluent: A review', Bioresource Technology, 77(3), pp. 275-286. doi: 10.1016/S0960-8524(00)00060-2. 
Utomo, N. B. P. et al. (2005) 'Pertumbuhan Spirulina platensis yang Dikultur dengan Pupuk Inorganik (Urea, TSP dan ZA) dan Kotoran Ayam', Akuakultur Indonesia, 4(1), pp. 41-48.

Vieira Costa, J. A., Colla, L. M. and Duarte Filho, P. F. (2004) 'Improving Spirulina platensis biomass yield using a fed-batch process', Bioresource Technology, 92(3), pp. 237-241. doi: 10.1016/j.biortech.2003.09.013.
Vonshak, A. (1997) Spirulina platensis (Arthrospira): Physiology, Cell-biology and Biotechnology. Vonshak,. Edited by A. Vonshak. London: Taylor \& Francis.

Yuan, X. et al. (2011) 'Impact of ammonia concentration on Spirulina platensis growth in an airlift photobioreactor', Bioresource Technology, 102(3), pp. 3234-3239. doi: 10.1016/j.biortech.2010.11.019. 
- Halaman ini sengaja dikosongkan - 